\title{
Information and communicative component of an international scientific discourse
}

\author{
Anastasiia Sibruk ${ }^{1}$, Viktor Sibruk ${ }^{1}$, Nadiia Senchylo-Tatlilioglu ${ }^{1}$, Svitlana Lytvynska ${ }^{1}$, \\ Volodymyr Varenko ${ }^{2}$, and Lina Storozhenko ${ }^{3}$ \\ ${ }^{1}$ National Aviation University, Liubomyra Huzara ave 1, 03058, Kyiv, Ukraine \\ ${ }^{2}$ National University of Culture and Arts, Yevhen Konovalets Street 36, 01601, Kyiv, Ukraine \\ ${ }^{3}$ State University of Telecommunications, Solomianska Street 7, 03110, Kyiv, Ukraine
}

\begin{abstract}
Abstract. For a comprehensive study of tropes and stylistic figures of the Ukrainian language is extremely important to learn the basic functions of tropes in the scientific linguistic articles. The actuality of the research topic is determined by the need of a systematic study of tropes and stylistic figures that are traditionally considered unusual for the text, but we will try to prove that they are relevant. In modern scientific literature, the expressive and emotional function is presented and implemented by the help of such tools as epithets and metaphors. The study of the linguistic features of scientific discourse is of great importance to find ways of explaining a certain material. The study, using a free associative experiment, has led to the conclusion that the use of artistic means and stylistic figures in the educational and scientific texts makes it possible to master the material better. Generally speaking, the use of artistic means in scientific texts is not widespread, but the student audience prefers these texts. The use of metaphors, epithets, phraseologisms, comparisons, periphrases in professional articles is an effective way of highlighting important elements of scientific discourse, forming the individual style of the researcher. If the text is addressed to the reader for educational purposes, the correct use of paths will facilitate the quickest possible understanding of the basic thought of the message. In our view, a promising direction is the further study of communicative analysis of tropes in scientific texts.
\end{abstract}

Keywords: scientific discourse, tropes, metaphors, stylistic figures, experiment.

JEL Classification: $H 5, H 51, R 4$

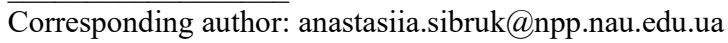




\section{Introduction}

The role of science in society has grown tremendously in recent decades. The linguistic quality of academic works significantly affects its theoretical and practical value. Due to rapid progress, in particular, in technical sciences, linguistic, stylistic, psycholinguistics, and pragmatic features of scientific communication are in the severe interests of linguists. However, the current level of scientific language culture testifies to a large number of problems, including insufficient linguistic, communicative, and stylistic competencies of researchers. Quite often in modern linguistic literature, science is referred to as a kind of discourse. The many definitions that give this phenomenon, incredibly complicates the procedure of outlining its attributes and characteristics.

Studies of the use of tropes in modern Ukrainian academic discourse refers to the actual tasks of Ukrainian linguistics. In this aspect, special importance is given to the systematic analysis of vocabulary, because the use of various tropes affects the reader's reaction, and this already belongs to psycholinguistics.

The relevance of this scientific work is determined by the need for a systematic study of lexemes and syntactic combinations, which are traditionally considered uncharacteristic of a scientific text, but we will try to prove their relevance. Peculiarities of linguistic and stylistic design of scientific discourse are covered in the works of such scientists: J. Ahmad (2012), P. Bizzell (1999), R.A. Day, N. D. Sakaduski (2011), F. Salager-Meyer (2011), J. M. Swales (1990), J. Lakoff (2004), M. Kotyurova (2004), N. Nepiyvoda (2011), O. Ilchenko (2012), P. Seligey (2016), and others $[1 ; 2 ; 3 ; 4 ; 5 ; 6 ; 7 ; 8 ; 9 ; 10 ; 19-21]$. However, this aspect has not been studied enough in the scientific literature.

The purpose of the article is to clarify the semantic content and functions of different types of tropes in scientific texts. Achieving this purpose involves the following tasks: to identify the main types of tropes in scientific texts; clarify the semantic content of tropes in scientific discourse; to prove the expediency of motivating the use of tropes in professional works; identify psycholinguistic features of the use of tropes in scientific texts. The subject of research is the place of tropes in scientific discourse. The object of research is stylistic figures selected from modern Ukrainian linguistic literature.

Such functional properties as expressiveness and evaluability deserve special attention during the research of a scientific text. The scientific text is characterized by the use of abstract vocabulary, emotionally neutral elements, commenting components, clichés, etc. to achieve accuracy, unambiguity, the logic of exposition. Clear logic and a kind of "dryness" of scientific exposition do not preclude the use of emotionally expressive means of language. Modern linguists (G. Dyadyura, M. Kotyurova) [11;7] claim that both logical and figurative thinking take part in the formation of scientific thought; only in a scientific text does imagery focus primarily on the reader's intellect, and only then on his emotional perception, and informs not only about the object but also the subject of cognition.

\section{Aim and tasks}

The aim of the article: define the basic requirements for the aviation term as a unit of terminological system. Main research tasks: to analyze the existence of synonymy and insufficient accuracy of aviation terms, to describe the process of integration of national terminology.

\section{Research methods}

To determine the psycholinguistic features of the contextual implementation of tropes in scientific discourse, we used the method of a free associative experiment. The freeassociative experiment was carried out from September 1, 2019 to December 19, 2019 as part of the study by students of the discipline "Business Ukrainian Language". To acquaint the audience with the fourth topic of the curriculum "Scientific communication as a 
component of professional activity" students were offered various scientific articles, where each had to choose only one article to study and justify their choice. Participants were not restricted in their choice of possible associations. This experiment made it possible to establish an additional connotation of individual tropes.

The associative experiment was attended by 80 respondents studying at the National Aviation University of Ukraine, including: by age criteria (students from 17 to 25 years); by gender ( 38 females and 42 males); by field of study (40 students of the Faculty of Linguistics and Social Communications, 40 students of the Faculty of Air Navigation, Electronics and Telecommunications). In order to systematically and comprehensively study the psycholinguistic features of the main types of tropes used in linguistic texts and to express the scientific statement, we used the following methods: descriptive, structural, statistical and regressive analysis.

The main source of material was the linguistic works of P. O. Seligey $[10 ; 12 ; 13]$, N. F. Nepiyvoda [14] and other Ukrainian scientists. The theoretical value of the work is that a comprehensive lexical and semantic analysis of tropes expands scientific ideas about the nature and patterns of vocabulary formation of a scientific text. The practical value of the study is determined by the possibility of using its results in teaching courses in psycholinguistics, lexicology, stylistic, and culture of the Ukrainian language; use of emotional vocabulary in order to faster assimilation of the material by students.

\section{Research results}

One of the directions of modern research in the field of psycholinguistics is the consideration of the main features and patterns of functioning of different types of texts in the scientific area, as well as the specifics of scientific style as a result of the interaction of linguistic and extralinguistic factors. The scientific discourse of the Ukrainian language has its own peculiarities. Its task is to accurately present scientific information, serves the needs of science, education, and training. The main function of scientific discourse is cognitive and informative (messages, explanations, classification of concepts, systematization of knowledge, reasoned proof).

We believe that every scientific text is a system of subtexts. The subtext is a fragment of the whole text, which realizes in it one of the aspects of the cognitive situation (ontological, methodological, axiological, communicative, etc.).

When preparing a scientific text, the researcher always takes care of the individuality of the method of writing. Obviously, the main features of a scientific text are a clear, logical structure, objectivity, coherence, integrity, articulation, informational, logical, emotional and evaluative saturation, completeness, the presence of terminology, and so on. The integrity of a scientific text presupposes internal organization, semantic unity, integral design of the beginning and end of the work, transitions between parts of the text, which is provided by certain linguistic units. The sequence in the scientific text is realized through special functional and syntactic means that indicate the sequence of thought development (first, then, now), the transition from one thought to another (consider, let's stop at ..., considering ..., let's move on...), result, conclusion (therefore, summarize ...).

Communicativeness is realized in the focus of the text on the recipient. Appropriate writing style of a certain author helps to achieve addressability. Stylistic figures and tropes help to deepen the text, simplify or, conversely, complicate it, deepen the semantics.

During the experiment with students, the issue of creating a scientific text was considered, a list of literature from 20 sources was given, each participant had to choose only one source for processing. For the correctness of the experiment, such works were selected that are freely available on the Internet and have approximately the same number of pages. The fact that 78 $(97.5 \%)$ students chose only the works of three authors turned out to be interesting. Online textbook L. Matsko "Stylistics of the Ukrainian language" was chosen by six students (7.5\%) 
[15]. Seven (8.75\%) participants preferred the scientific article by N. Nepiyvoda [8]. Author of the scientific work: An attempt at a psychological portrait (Based on V. Rusanovsky's book "History of the Ukrainian literary language. Textbook" [8]. Most students (65 students - 81.25\%) chose scientific articles by P. Seligey 2006, 2014, 2016 [10; 12; 13]. The main task was to understand the psycholinguistic reasons for choosing works. The answer of absolutely all students was the same. Respondents answered that the material was easy to learn because it was written in clear and understandable language using a variety of artistic means and stylistic figures.

Then the students were offered another task. They had to write from scientific works artistic means and stylistic figures that they liked. To perform this task during the practical lesson, the respondents were given the material of scientific articles by P. Seligey and N. Nepiyvoda. In one academic hour (45 minutes), everyone had to write phrases or sentences that contained emotional elements.

Among the tropes, the participants of the experiment chose the most expressions using metaphors in professional tests. Metaphorization of a scientific text is a rather extensive and diverse process that leads to the acquisition of new knowledge about the world through the use of already existing names in the language. The role of metaphor is that by using old words to perform new functions, we obtain savings in the lexical means of speech and use our habits in the process of creating new figurative meanings. To understand a metaphor means, to a certain extent, to mentally trace the path of its creation, to understand its psycholinguistic aspect. The task of the metaphor is to evoke the reader's imagination, to influence consciousness. In general, the metaphor of speech is related to polysemy, because polysemy is inherent in most ordinary words, which is quite natural, because words as names can easily pass from one thing to another or to some feature of that thing or part of it. Therefore, the question of "polysemy is first of all a question of nomination, ie change of things at identity of a word. The question of the preservation and permanence of the concept or its essential features is expressed in polysemy in different ways" [16, p. 57].

The students noted that these statements evoked clear associations with the environment and seemed to bring the scientific text closer to real life, to enliven it. In general, students of the humanities were more active, in 45 minutes a total of 28 metaphors were found in scientific texts, students of technical specialties found only 12 such elements. The task interested mainly a female audience of 28 metaphorical expressions, 21 were called by the girls. Here are the quotes were chosen by the participants of the experiment. The reader's imagination is clearly traced by reading the following quote: "I recognized that the dominance of these nouns gives the text a stationery flavor" [12, p. 45]. Most students of humanities and technical specialties wrote this quote (52 students - 65\%). Quotes, where metaphor is uncharacteristic, are also not left out, so the researcher quotes it: "Scientific thinking seeks to systematize and symbolize, thereby curtailing, "condensing" experience, reduces the diversity of knowledge to a common denominator" [10, p. 22]. Quotes (tropes) in quotes were interested in students of technical specialties, out of 43 students who wrote this quote, 31 students' study at the Faculty of Air Navigation, Electronics and Telecommunications.

Sometimes the metaphor has a negative connotation, "If the pen master venomously delineates the mock abusing of the verbal nouns" [10, p. 44]. In this passage, we consider it necessary to emphasize the use of the adjective venomously that hyperbolizes metaphor. The emotional vocabulary in this sentence was noticed by humanities students and two representatives of technical specialties; of them - 28 ladies.

In general, the metaphor is presented in all styles of modern Ukrainian literary language. However, we were interested in its implementation in the scientific text and its impact on the assimilation of new material. Other quotations are much less common in student works. Here 
are the following examples: "presented in a number of monographs" [8, p. 159]; "This property makes them a powerful weapon of thought" [8, p. 160].

As a result of the experiment, nominative metaphors were clearly distinguished, which are based on an unconditional analogy: "in terms of content poverty" [10, p. 18]; "Language for the author is a living organism" [14, p. 162]. In the text, these metaphors were found by 24 students (14 representatives of technical specialties and 10 - humanities).

Sixteen students drew attention to certain metaphors close to phraseological expressions: "scientific thought seeks to free itself from the shackles of subjectivism, and this also activates the nominal type of speech" [12, p. 36]; "Phrases with a stringing of dependent nouns" [12, p. 37].

Examining scientific speech, we singled out the metaphorical statements of P. Seligey: "The need for such exploration for the recovery of written scientific speech is obvious" [10, p. 13]; "The media style fell ill with ideological stereotypes" [13, p. 174]. Unfortunately, these language units are reflected only in students of the Faculty of Linguistics and Social Communications.

M. Murphy notes that the norm of the word and the change of meanings are related to the mentality of the society in which it operates [17, p. 6-8]. At the intersection of figurative and nominative metaphor is the word hygiene, used in an atypical sense: "Fixing and correcting common mistakes, it conducts a kind of hygiene of public broadcasting and thus increases the level of mass literacy" [10, p. 10]. None of the respondents did pay attention to this trope. Perhaps most students have decided that this is a well-established term.

Only the most attentive respondents found and wrote the following metaphors and metaphorical expressions: "if the critic is armed with methods of linguistic analysis" [10, p. 12]; "Here, of course, we cannot but recognize the" insidious "role of language" [12, p. 48].

N. Nepiyvoda not only studied the paths in a foreign language, but also was a master of extraordinary metaphorization of a scientific text. We want to quote the following statements: "words are "surface structures"", "it allows to "insure "", "the author "dedicates" the reader" $[8$, p. 172, 160, 168]. The linguist actively draws metaphors into the scientific text, but there is some caution about such use. Therefore, in the articles of N. Nepiyvoda most of the author's phraseology is quoted. Students of the Faculty of Linguistics did not pay attention to such phrases, six students of technical specialties found these quotations in scientific papers.

In general, metaphors do not occur very often in linguistic works. The leader in the metaphorization of scientific texts, in our opinion, is P. Seligey. His scientific style is close to popular science. Of course, this style is very popular with students, associative thinking affects the reader's perception and helps to understand the text. In general, metaphors play a huge role in the formation of scientific and popular science linguistic text. They form a "bridge" between the linguistic material and the personal experience of the reader, are the link between the semantic spaces of the sender and recipient of the message.

An important object of psycholinguistic analysis has become the epithet as a linguistic means of expression that plays a significant role in creating a linguistic picture as an individual. Therefore, the study of the epithet has certain traditions in lexicology, linguistic stylistics, literary theory and psycholinguistics. In the researched articles, students of both humanities and technical specialties found 11 cases of using epithets.

Let's analyze the following quote by P. Seligey, which was found by 47 students: "Good awareness of the arsenal of means of expression liberates speech, makes it flexible, concise, accurate, perfect" [10, p. 9]. On the one hand, the phrase "good awareness" can be used as a synonym for the expression "high awareness". However, it is possible to consider "good" as a synonym used for the purpose of positive connotation. The linguist can also find epithets aimed at a negative connotation: "careless term usage and other abuses of language were analyzed or mentioned ..." [10, p. 10]. 
Respondents noted the following quotes with the use of epithets: "The author carefully bypasses the sharp corners"; "In vain texts, frequency terms denoting" fashionable "concepts" [10, p. 18]; "The "negative" language material is also useful" [12, p. 26].

Exploring linguistic material 36 students paid attention to this quote: "The distinctive scientific text provokes mental activity keeps opinion in tension, stimulates independent thinking" [10, p. 20]. Of course, this quote can be considered as an example of metaphorization, but, in our opinion, it would be more appropriate to consider verb constructions in this sentence as vivid examples of epithet and hyperbole. As the author tries to exaggerate and poetically depict the meaning, to make the reader think about the importance of what is said.

By analogy with the metaphorical examples, 32 technical students wrote quotes with tropes in quotes: "This is in line with the position of modern neurolinguistic programming that written and spoken words are 'surface structures', which in turn constitute transformed mental and linguistic "deep" structures" [8, p. 160]. The author does not take some epithets in quotation marks and combines them with metaphors: "Hence at least two features of the scientist: respect for language, its fascination with potentially infinite possibilities" [8, p. $160]$.

The originality of the epithet of scientific style is manifested in the degree of stability and novelty, in direct, figurative, symbolic meanings, in grammatical forms of functioning, in the emphasis on various features of an object or phenomenon (visual, emotional, and psychological).

In some articles, you can find catchphrases. Seventy-seven students $(96.25 \%)$ noted a phraseology used in the title of the article: "Noun Versus verb: in search of the golden mean" [12, p. 36]. More attentive (23 students) found the phraseology in the article: "By consistently adhering to this norm, we will be able to find the golden mean between nouns and verbs in a scientific text" [12, p. 53].

"The language in which scientific and technical facts are expressed is certainly not a different language from that of everyday life" [18, p. 2]. Much more often in a scientific text, you can see a comparison, the simplest example of a trope, which is close to metaphor and epithet, enriches the meaning of a word or phrase. In our opinion, comparisons in scientific or another style of literature are used in order to enrich the meaning of a particular word or phrase, to evoke in the reader associative thinking. Often the comparison helps the reader to understand the text, to learn complex phenomena through simple ones. Comparison is also a vivid means of assessing the surrounding reality so that the author in his research has the opportunity to identify emotional attitudes to what he writes. However, only two comparisons were recorded during the experiment. Forty-three students noticed the following quote: "Hypostasic inevitably leads to the fact that the world seems to "double", there is confusion" [12, p. 48]; Twenty-one respondents recorded this passage of linguistic work: "The information system of the organization, its information resources are the nervous system of any management system (V. Guzhva). Just as in a good owner's pantry, different things are arranged on certain shelves and boxes, so in the arsenal of facts that chemistry operates on them, a rational system is an indispensable condition (O. Golub)" [10, p. 24]. Comparison is an essential means of expressing a scientific text because often too complex concepts can be explained only by comparisons and analogies.

An important element of scientific discourse is periphrasis. In scientific texts, periphrases are often used to avoid repetition, but also to express owns (author's) attitude to the object of the story. The function "name in a new way" is realized through the use of paraphrases. During the experiment, almost 78 students wrote a quote from P. Seligey: "Having gained state status, it has taken its rightful place in the scientific field and is now part of the "elite club" of the few languages in which scientists publish their intelligence" [10, p. 1]. In our opinion, the fact that almost all students paid attention to this stylistic figure indicates the 
sharpness and accuracy of the author's thought. In scientific texts have also managed to record paraphrases that are constant expressions or terms today: "If the pen master venomously delineates the mock abusing of the verbal nouns" [12, p. 44]; "distorted scientific speech "scientific jargon"' [10, p. 4]. The first quote was singled out by 23 students, the second 16.

Thus, the participants of the experiment singled out the following types of artistic means and stylistic figures: metaphors, epithets, phraseologies, comparisons, paraphrases. The indicators of the experiment of students of different faculties differ. Respondents from the Faculty of Linguistics and Social Communications were more attentive to the experiment, found more metaphorical expressions than students of technical specialties. Figures 1 and 2 show the percentage of tropes and stylistic figures found in scientific articles.

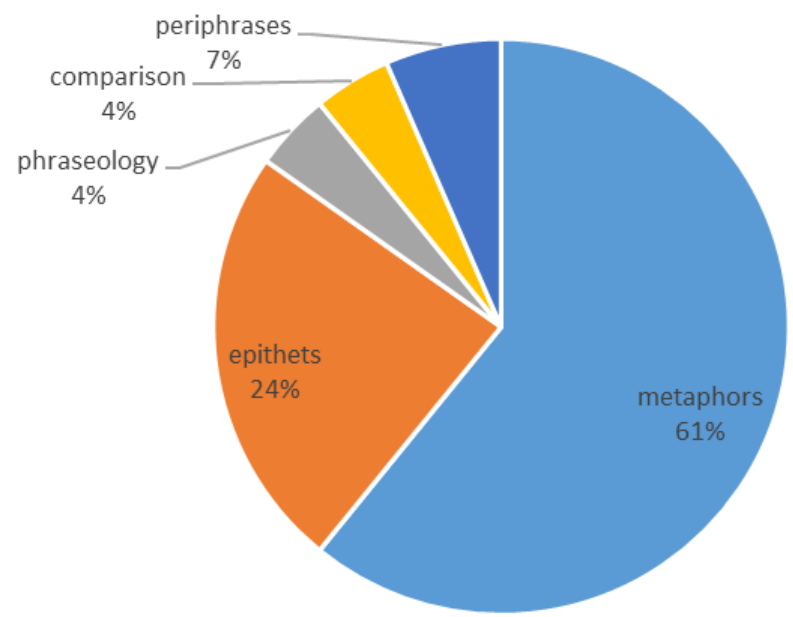

Figure 1: Tropes and stylistic figures in scientific articles (students of the Faculty of Linguistics and Social Communications)

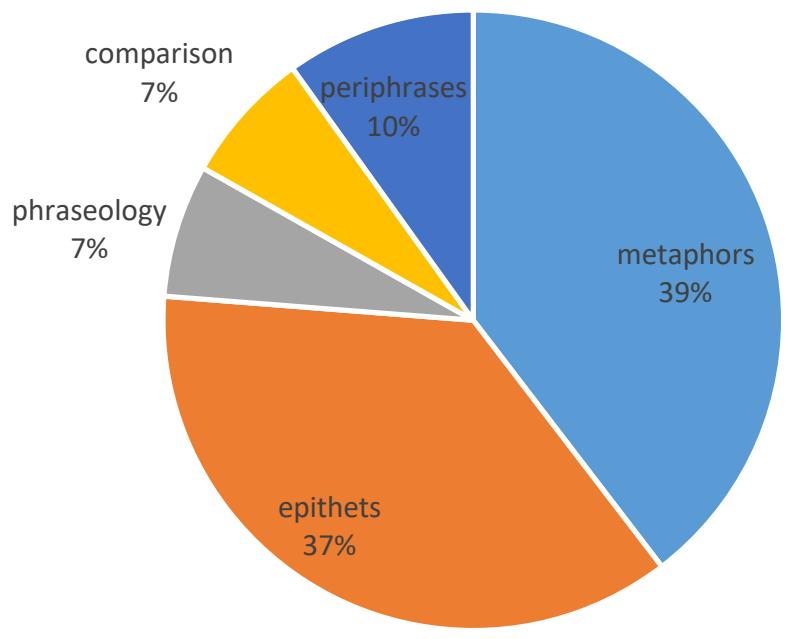

Figure 2: Tropes and stylistic figures in scientific articles (students of the Faculty of Air Navigation, Electronics and Telecommunications) 
We tried to analyze how students will learn the material using the method of regression analysis, determining the separate and joint influence of factors on the performance trait and quantifying this impact by using appropriate criteria. Regression analysis is performed on the basis of the regression equation and determines the contribution of each independent variable to the variation of the studied dependent variable.

Using Excel calculations, an expert group of three research and teaching staff of the National Aviation University assessed the degree of mastering the material on a scale from 1 to 10 , taking into account the number of citations with epithets and metaphors written by respondents. Our main task was to understand how much the level of assimilation of new material depends on the number of written artistic means. A statistical analysis of the results of our observations was performed.

The sample size consisted of 80 respondents from among students who had to mention texts that include metaphors and epithets. Each of the respondents was given an expert assessment of text acquisition on a scale from one to ten, where one is the lowest score and ten is the maximum score. The correspondence between the assessment of each respondent and the number of metaphors and epithets mentioned by him was also calculated. Based on the results of the survey, we compiled a table of correspondences between the assessments of the expert survey and the number of metaphors and epithets. The results can be seen in Figure 3.

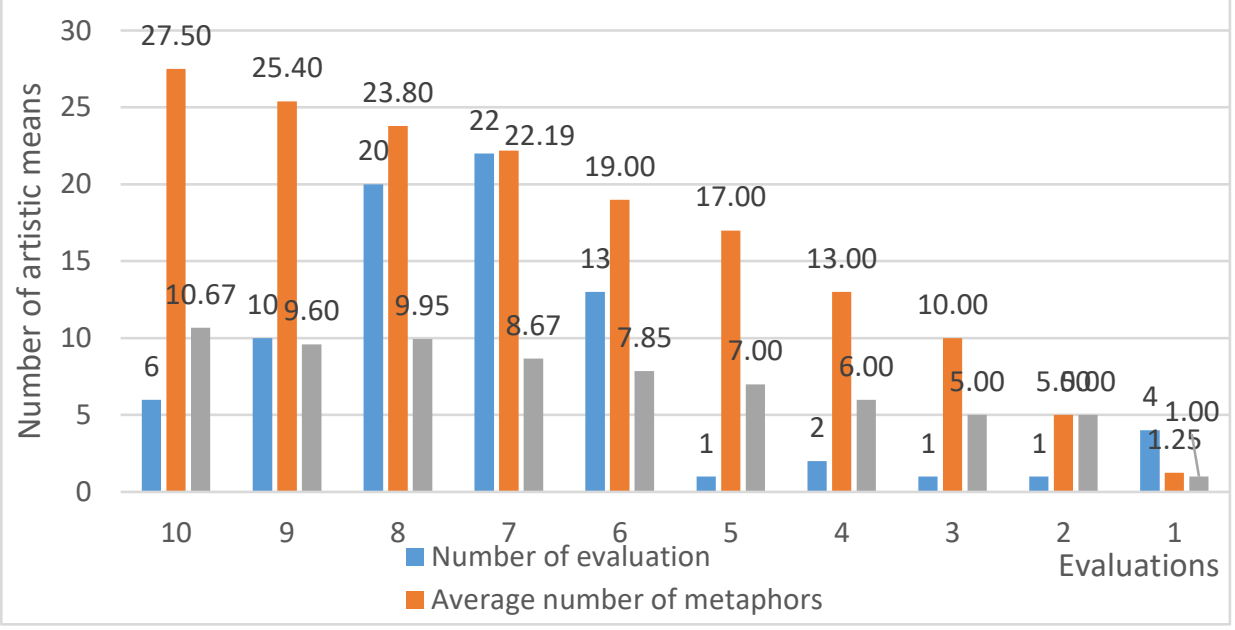

Figure 3: The ratio of the degree of assimilation of the text and artistic means.

The graph clearly shows that the degree of assimilation of the material by students depends on how many artistic means and stylistic figures the respondents noticed from the scientific text.

We have attempted to quantify the dependence of the degree of assimilation on the use of metaphors and epithets in texts. To do this, we used the method of regression analysis to identify patterns between the dependent indicator of the degree of assimilation of the text and the independent factors influencing epithets and metaphors.

We present the results of the analysis in the form of the dependence, based on the hypothesis of the linear nature of the relationship between the indicator and factors $y=a 0+$ $\mathrm{a} 1 \mathrm{x} 1+\mathrm{a} 2 \mathrm{x} 2$, where $\mathrm{y}-$ assessment of text acquisition, $\mathrm{x} 1$ - metaphors, $\mathrm{x} 2$ - epithets, a1 and a2 - unknown parameters models to be defined.

We first determined the degree and strength of the relationship between y and factors using Pearson's pairwise correlation coefficient, $\mathrm{k} 1=0.97, \mathrm{k} 2=0.94$. In both cases, the coefficients are positive and the values of coefficients exceed 0.9 , which indicates a close 
relationship, ie regression analysis can be performed. We will also perform an analysis using the one-step method of least squares in MS Excel. The results of constructing the regression equation are: $\mathrm{y}=-0.17+0.276 \times 1+0.163 \times 2$. The model was tested for adequacy according to Fisher's criterion: $\mathrm{F}>\mathrm{Ft}(624,5489>2,59)$, which means that the model can be considered adequate.

The analysis allows us to make predictions about the dependence of the degree of assimilation of texts from the use of special artistic techniques. So, for example, at application in the text of the average size (10-15 pages) approximately 10 metaphors and 10 epithets then it is possible to expect on average degree of mastering will make 4,2 $(-0,17+0,27 * 10+$ $0,163 * 10=4.2)$. This is a positive indicator of the significant influence of artistic means on the memorization of the text.

\section{Conclusions}

The study using a free-associative experiment gave grounds to conclude that in educational and scientific texts the use of artistic means and stylistic figures allows for better assimilation of the material. In general, the use of artistic means in scientific texts is not common, but the student audience prefers such texts. The use of metaphors, epithets, phraseologies, comparisons, paraphrases in professional articles is an effective way to highlight important elements of scientific discourse, the formation of the individual style of the author. Not excessively, but accurately applied expressiveness not only attracts the reader but also makes the text more vivid and expressive. The presence of tropes makes it possible to popularize complex scientific developments, because the reader, for objective reasons, cannot gain his own experience in the described field, to verify the authenticity of the situations proposed by the author. "Live" text has a positive effect on the reader and allows quickly learn and remember reading material. Also, the important function of the tropes in these materials is to transmit to the reader the emotions of the author, personal expressive attitude to the described phenomena.

A wide arsenal of stylistic means and language techniques allows figurative words to influence the mind and feelings of the recipient. The author's individuality is manifested in the use of language, the characteristic manner of choice, and the use of words. All stylistic linguistic means of a scientific text are aimed at the perception of a professional text and understanding of its content. The use of tropes in professional linguistic works performs the following functions: replacement of complex concepts and terms, visualization of individual terms, broadcasting to the reader the emotions of the author, establishing mutual understanding between the author and the reader.

The metaphor in the scientific discourse deserves special attention because it is this artistic means that the respondents remember the most. The metaphor represents new aspects of the content of concepts, reveals non-traditional semantic meanings, focuses the addressee's attention on the essence of a new scientific phenomenon. The use of metaphors in the language of science facilitates the interpretation of scientific discourse, as it allows us to consider the phenomenon in many ways and in comparison, with other phenomena allows us to see the dynamics of their development. The use of epithets in linguistic professional research performs expressive and evaluative functions. They give a positive or negative connotation to the text. If the epithet is unusual for perception, the author takes it in quotation marks.

Thus, if the text is addressed to the reader for educational purposes, the accurate use of tropes will help to quickly understand the main idea of the message. In our opinion, the direction of further research of psycholinguistic analysis of tropes in scientific texts is promising. 


\section{References}

1. Ahmad J. (2012). Stylistic Features of Scientific English: A Study of Scientific Research Articles // English Language and Literature Studies. 2012. Vol. 2. № 1. P. 47-55. URL : www.ccsenet.org/ells.

2. Bizzell P. (1999). Hybrid Academic Discourses: What, Why, How // CompositionStudies. 27. P. 7-21.

3. Day, R. A., Sakaduski. N. D. (2011). Scientific English: A Guide for Scientists and Other Professionals. URL: http://www.abc-clio.com/product.aspx?id=2147491826.

4. Francoise Salager-Meyer. (2011). Scientific discourse and contrastive linguistics: hedges. European Science Editing, 37(2). p. 36. URL: http://www.ease.org.uk/pdfesearticlesmay11/salager-meyerArticle35-37.pdf

5. Swales J. M. (1990). Genre analysis: English in academic and research settings // Cambridge: Cambridge University Press, 1990. URL: https://kupdf.net/download/swales-j-1990-genreanalysispdf 5964dbcddc0d60af392be317 pdf

6. Lakoff, Dzh. \& Dzhonson, M. (2004). Metaforyi, kotoryimi myi zhivem. Moskva: Editorial URSS. $256 \mathrm{~s}$ [in Russian].

7. Kotyurova, M. P. (2004). Stilistika nauchnoy rechi: ucheb. posob. dlya stud. uchrezhdeniy vyissh. prof. obrazovaniya. Moskva. 240 [in Russian].

8. Nepyivoda, N. (2011). Avtor naukovoho tvoru: sproba psykholohichnoho portreta (Na materiali knyhy V. M. Rusanivskoho «Istoriia ukrainskoi literaturnoi movy. Pidruchnyk» «Istoriia ukrainskoi literaturnoi movy. Pidruchnyk» (K., 2001. (K., 2001. - 392 s.))* 392 s.)). Styl i tekst, 12, 159-178 [in Ukrainian].

9. Ilchenko, O.M. (2012). Dyskursyvna koherentnist ta vzaiemodiia naukovoho dyskursu $z$ inshymy $v$ konteksti postmodernizmu. Linhvistyka KhKhI stolittia: novi doslidzhennia perspektyvy. 124-131. http://langcenter.kiev.ua/Lingvistika\%202012/Ilchenko\%20Shalya\%20124-133.pdf [in Ukrainian].

10. Selihei, P.O. (2016). Ukrainskyi naukovyi tekst: problemy komunikatyvnoi povnotsinnosti ta stylovoi doskonalosti. Kyiv. (Avtoreferat). $36 \mathrm{~s}$ [in Ukrainian].

11. Diadiura, H.M. (2013). Obraznist yak zasib dialohichnosti naukovo-populiarnoho tekstu. Styl i tekst, 4, 120-127 [in Ukrainian].

12. Selihei, P. (2014). Imennykovist Versus diieslivnist: u poshukakh zolotoi seredyny. Movoznavstvo, 4, 36-55 [in Ukrainian].

13. Selihei, P.O. (2006). Naukovyi styl ukrainskoi movy: resursy onovlennia. Movoznavstvo, 2-3, 174-186 [in Ukrainian].

14. Nepyivoda, N.F. (1997). Mova ukrainskoi naukovo-tekhnichnoi literatury (funktsionalno-stylistychnyi aspekt). Kyiv: TOV «MFA». $303 \mathrm{~s}$ [in Ukrainian].

15. Matsko, L. I. (2003). Stylistyka ukrainskoi movy. Pidruchnyk. Kyiv: Vyshcha shk. 462 $\mathrm{s}$ [in Ukrainian].

16. Sibruk, A.V. (2011). Struktura ta semantyka nazv prykras (na osnovi pamiatok KhI$K h I V$ ct.). Kyiv. (Dysertatsiia). 266 s [in Ukrainian].

17. Murphy, M. (2003). Semantic relations and the lexicon. Cambridge. 278 p. [in English].

18. Herbert, A.J. (2011) The structure of Technical English. URL: http://eng.harran.edu.tr/ hbulut/The_Structure_\%20of_Technical_English2\%20(1).pd $\mathrm{f}$

19. Gudmanian A., Yahodzinskyi S., Koshetar U., Orochovska L. (2019) Social and economic aspects of environmental problems in the globalized world. E3S Web Conf. 
Topical Problems of Green Architecture, Civil and Environmental Engineering 2019 (TPACEE 2019). - 2020 - Volume 164. URL:

https://doi.org/10.1051/e3sconf/202016411019

20. Koshetar U., Orochovska L. Social atomization as a phenomenon of information society. Trends and prospectsfor the world economy and international economic relations: Collective monograph / Edited by Walery Okulicz-Kozaryn Czestochowa: Polskie towarzystwo ekonomizne, 2020. - P. 17-35.

21. Burlakova I., Sibruk A., Khalinovska L., Sibruk V. Terminological modelling of the aviation terms system in the context of globalized information space and security of aviation industry // IOP Conf. Series: Materials Science and Engineering: VIII International Scientific Conference Transport of Siberia, 2020, Volume 918. DOI: https://doi.org/10.1088/1757-899X/918/1/012085. 